Article

\title{
Electrochemical Conversion of the Lignin Model Veratryl Alcohol to Veratryl Aldehyde Using Manganese(III)-Schiff Base Homogeneous Catalysts
}

\author{
Lara Rouco ${ }^{1}$, M. Isabel Fernández-García ${ }^{1}$, Ana M. González-Noya ${ }^{2}$, \\ Gustavo González-Riopedre ${ }^{1,3}$, Alexei M. Tyryshkin ${ }^{4}$ and Marcelino Maneiro ${ }^{1, * \mathbb{C}}$ \\ 1 Departament of Inorganic Chemistry, Faculty of Sciences, University of Santiago de Compostela, \\ 27002 Lugo, Spain \\ 2 Departament of Inorganic Chemistry, Faculty of Chemistry, University of Santiago de Compostela, \\ 15782 Santiago de Compostela, Spain \\ 3 ENCE Navia Biofactory, Armental, 33710 Navia, Spain \\ 4 Department of Marine and Coastal Sciences, Rutgers, The State University of New Jersey, New Brunswick, \\ NJ 08901, USA \\ * Correspondence: marcelino.maneiro@usc.es; Tel.: +34-982-824-106
}

Received: 22 July 2019; Accepted: 16 August 2019; Published: 20 August 2019

Featured Application: Kraft pulp bleaching and delignification.

\begin{abstract}
Lignin and other colored structures need to be bleached after the Kraft process in the pulp industry. Development of environmentally-safe bleaching catalysts or electrocatalysts constitutes an attractive strategy for selective removal of lignin. Seven manganese(III)-complexes with Schiff base ligands 1-7 were synthetized and characterized by different analytical and spectroscopic techniques. The tetragonally elongated octahedral geometry for the manganese coordination sphere and the global $\mu$-aquo dimeric structure were revealed by X-ray diffraction (XRD) studies for 1, $\mathrm{Mn}_{2} \mathrm{~L}_{2}{ }_{2}\left(\mathrm{H}_{2} \mathrm{O}\right)_{2}\left(\mathrm{~N}(\mathrm{CN})_{2}\right)_{2}\left(\mathrm{~N}(\mathrm{CN})_{2}=\right.$ dicyanamide). Complexes 1-4 behave as more efficient peroxidase mimics as compared to 5-7. Electrochemical oxidation of the lignin model veratrylalcohol (VA) to veratrylaldehyde (VAH) is efficiently catalyzed by a type of dimanganese(III) complexes in a chlorine-free medium. The electrocatalytic reaction proceeds through the oxidation of chloride into hypochlorite at alkaline $\mathrm{pH}$ along with the formation of hydrogen from water as a subproduct.
\end{abstract}

Keywords: manganese; catalysts; electrocatalysts; peroxidases; lignin; kraft pulp; veratryl alcohol

\section{Introduction}

Lignin comprises polymerized phenolic and aliphatic-hydroxyl groups, being the most abundant renewable source of aromatic polymers in nature [1,2]. Historically, the degradation of lignin represented a major target in the pulp industry [3]. In order for the pulp to reach an acceptable brightness level, the residual lignin after the Kraft process was bleached either to remove it from the pulp or, alternatively, to decrease absorption by the residual chromophoric groups as much as possible [4]. Of all the processes involved in the manufacturing of pulp for the paper industry, the bleaching stage to degrade lignin is the step which contributes most to environmental pollution $[5,6]$. Several alternative bleaching processes have been developed to date including those using chlorine-free oxidants to make this challenging process more environmentally friendly [7-9].

A general problem with bleaching the small percentages of lignin and colored chromophores in a bulk matrix of cellulose is the lack of selectivity of the oxidation reaction. Therefore, the driving force in the development of new bleaching technologies is to produce pulps with the best brightness, 
lowest lignin and chromophore contents, while preserving the yield and strength of the fibers by minimizing cellulose degradation. Different sites in the cellulose matrix are susceptible to attack by oxidative agents: the damage may occur within the polysaccharide chains (oxidizing carbon positions of the monomeric sugar units to carbonyl groups which give rise to alkali-labile glycosidic bonds), or alternatively the end groups (oxidizing aldehyde groups that are formed after each cleavage of the glycosidic linkage) can be targeted.

In addition to lignin disposal in the pulp industry, another major goal in this field is the development of green and efficient methods to transform lignin into fuels and high value-added chemicals [10-12]. The polymeric structure of lignin provides an attractive renewable source of aromatic chemicals $[13,14]$. Catalysis is regarded as a key technology to fulfil the promise of lignin valorization. Catalytic systems for the reduction of lignin generally produce bulk chemicals with reduced functionality, whereas catalytic systems for lignin oxidation produce fine chemicals with increased functionality $[15,16]$. The chemical processes occurring in pulp with dioxygen and hydrogen peroxide under alkaline conditions are quite similar. When oxygen reacts with the substrate, it may be reduced to water by four successive one-electron transfer steps giving rise to intermediate products such as hydroperoxyl radicals, hydrogen peroxide, hydroxyl radicals and their organic counterparts. The reaction of the peroxo intermediates can proceed heterolytically (formation of ionic species) or homolytically (formation of radical species). Controlling these two pathways and favoring the heterolytic pathway is a key of selectivity.

We previously reported several homogeneous catalysts for the oxidation of lignin model compounds and these systems were inspired by examples of efficient catalyst systems capable of performing transformations that are already found in nature [17-20]. Manganese(III) Schiff base complexes have long been known to be effective catalysts for the oxygenation of both saturated and unsaturated hydrocarbons [21,22]. Oxygen-nitrogen-nitrogen-oxygen (ONNO) Schiff base ligands with strong chelate effects are able to stabilize the manganese ion in various oxidation states since the two donor atoms of the chelated Schiff base exert two opposite electronic influences: the phenolate oxygen is a hard donor that is known to stabilize the higher oxidation state of the metal ion, whereas the imine nitrogen is a softer donor with a tendency to stabilize the lower oxidation state [23,24].

In the work described here, we further explored these biomimetic systems in order to study their synergistic effect in catalysing the electrochemical oxidation of the lignin model compound veratrylalcohol (VA) to veratrylaldehyde (VAH) [25]. We report the electrocatalytic behaviour of seven manganese(III) complexes that incorporate ONNO Schiff base ligands (depicted in Scheme 1).<smiles>CCOc1cccc(/C=N/CC/N=C/c2cccc(OCC)c2O)c1O</smiles><smiles>COc1cc(Br)cc(/C=N/CC(C)/N=C/c2cc(Br)cc(OC)c2O)c1O</smiles><smiles>COc1cccc(/C=N/CCC/N=C/c2cccc(OC)c2O)c1O</smiles><smiles>CCCC(C)/C=N/C=N/C=C/c1cccc(OC)c1O</smiles><smiles>CCOc1cccc(C=NCCC/N=C/c2cccc(OCC)c2O)c1O</smiles>

Scheme 1. Structure of Schiff base ligands $\mathrm{H}_{2} \mathrm{~L}^{1}-\mathrm{H}_{2} \mathrm{~L}^{5}$. All the Schiff bases used in this study were prepared by condensation of the appropriate diamine with the corresponding benzaldehyde. 


\section{Materials and Methods}

Experimental details concerning materials, reagents and instruments used are available in the Supplementary Materials section.

\subsection{Synthesis of the Complexes}

Experimental procedure and characterization data for $\mathbf{1}, \mathbf{3}, \mathbf{5}$ and $\mathbf{6}$ are collected below. Synthesis and characterization of complexes 2 [26], 4 [17] and 7 [27] have been already reported (see Table S1).

$\mathrm{Mn}_{2} \mathrm{~L}_{2}^{1}{ }_{2}\left(\mathrm{H}_{2} \mathrm{O}\right)_{2}\left(\mathrm{~N}(\mathrm{CN})_{2}\right)_{2}(\mathbf{1})$ was obtained by a procedure which has been already reported [27] using $0.15 \mathrm{~g}(0.42 \mathrm{mmol})$ of $\mathrm{H}_{2} \mathrm{~L}^{2}, 0.12 \mathrm{~g}(0.42 \mathrm{mmol})$ of $\mathrm{Mn}\left(\mathrm{CH}_{3} \mathrm{COO}\right)_{2}$ and $0.04 \mathrm{~g}(0.42 \mathrm{mmol})$ of $\mathrm{NaN}(\mathrm{CN})_{2}$. Experimental details are available in the Supplementary Materials section. Yield: $0.15 \mathrm{~g}(70 \%)$. Calculated Elemental Analysis for $\mathrm{C}_{44} \mathrm{H}_{48} \mathrm{Mn}_{2} \mathrm{~N}_{10} \mathrm{O}_{10}$ (986.8): C, 53.5; H, 4.9; N, 14.2. Found: C, 53.0; H, 4.9; N, 13.9\%. Electrospray mass spectrometry (MS ES) $(\mathrm{m} / \mathrm{z}): 409\left[\mathrm{MnL}^{1}\right]^{+}$; $475\left[\mathrm{MnL}^{1}\left(\mathrm{~N}(\mathrm{CN})_{2}\right)\right]^{+}$. Infrared (IR) (potassium bromide, $\left.\mathrm{cm}^{-1}\right): v_{\text {asym }}(\mathrm{C} \equiv \mathrm{N}) 2268(\mathrm{~m}), v_{\text {sym }}(\mathrm{C} \equiv \mathrm{N})$ 2152 (vs), $v(\mathrm{C}-\mathrm{O}) 1252$ (s), $v(\mathrm{C}=\mathrm{N}) 1620$ (vs), $v(\mathrm{O}-\mathrm{H}) 3418$ (m). $\mu=5.0$ BM. ${ }^{1} \mathrm{H}$ nuclear magnetic resonance $(\mathrm{NMR})$ (dimethyl sulfoxide- $\left.\mathrm{d}_{6}, \mathrm{ppm}\right): \delta-20.7(\mathrm{H} 4),-29.8(\mathrm{H} 5) . \mathrm{E}_{\mathrm{ox}}=-0.085 \mathrm{~V} ; \mathrm{E}_{\text {red }}=$ $-0.165 \mathrm{v} ; \mathrm{E}_{1 / 2}=-0.125 \mathrm{~V} . \Lambda_{\mathrm{M}}=54 \mu \mathrm{S}$.

$\mathrm{MnL}^{3}\left(\mathrm{H}_{2} \mathrm{O}\right)\left(\mathrm{ClO}_{4}\right)(3)$ was obtained by a procedure which has been already reported [17] using $1.00 \mathrm{~g}(1.99 \mathrm{mmol})$ of $\mathrm{H}_{2} \mathrm{~L}^{3}, 0.72 \mathrm{~g}(1.99 \mathrm{mmol})$ of $\mathrm{Mn}\left(\mathrm{ClO}_{4}\right)_{2} \cdot 6 \mathrm{H}_{2} \mathrm{O}$ and $0.16(3.98 \mathrm{mmol})$ of $\mathrm{NaOH}$. Experimental details are available in the Supplementary Materials section. Yield: $0.82 \mathrm{~g}(60 \%)$. Calculated Elemental Analysis for $\mathrm{C}_{19} \mathrm{H}_{20} \mathrm{Br}_{2} \mathrm{ClMnN}_{2} \mathrm{O}_{9}$ (670.6): $\mathrm{C}, 34.0 ; \mathrm{H}, 3.0 ; \mathrm{N}, 4.2 \%$. Found: $\mathrm{C}$, 34.3; $\mathrm{H}, 3.4 ; \mathrm{N}, 4.1 \%$. MS ESI $(\mathrm{m} / \mathrm{z}): 553\left[\mathrm{MnL}^{3}\right]^{+} \mathrm{IR}$ (potassium bromide, $\left.\mathrm{cm}^{-1}\right): v_{3}\left(\mathrm{ClO}_{4}^{-}\right) 1121$, $v(\mathrm{C}-\mathrm{O}) 1294(\mathrm{~s}), v(\mathrm{C}=\mathrm{N}) 1615(\mathrm{vs}), v(\mathrm{O}-\mathrm{H}) 3425(\mathrm{~m}) . \mu=4.7 \mathrm{BM}$. $\mathrm{E}_{\mathrm{ox}}=-0.034 \mathrm{~V} ; \mathrm{E}_{\mathrm{red}}=-0.114 \mathrm{v} ; \mathrm{E}_{1 / 2}=$ $-0.074 \mathrm{~V} . \Lambda_{\mathrm{M}}=91 \mu \mathrm{S}$.

$\mathrm{Mn}_{2} \mathrm{~L}_{2}^{4}\left(\mathrm{H}_{2} \mathrm{O}\right)_{2}\left(\mathrm{~N}(\mathrm{CN})_{2}\right)_{2}$ (5) was obtained by the same procedure as $\mathbf{1}$, using $0.15 \mathrm{~g}(0.41 \mathrm{mmol})$ of $\mathrm{H}_{2} \mathrm{~L}^{4}, 0.11 \mathrm{~g}(0.41 \mathrm{mmol})$ of $\mathrm{Mn}\left(\mathrm{CH}_{3} \mathrm{COO}\right)_{2}$ and $0.04 \mathrm{~g}(0.41 \mathrm{mmol})$ of $\mathrm{NaN}(\mathrm{CN})_{2}$. Experimental details are available in the Supplementary Materials section. Yield: $0.13 \mathrm{~g}(70 \%)$. Calculated Elemental Analysis for $\mathrm{C}_{44} \mathrm{H}_{52} \mathrm{Mn}_{2} \mathrm{~N}_{10} \mathrm{O}_{10}$ (990.8): C, 53.3; H, 5.3; N, 14.1. Found: C, 52.8; H, 5.1; N, 13.9\%. MS ES $(\mathrm{m} / \mathrm{z}): 423\left[\mathrm{MnL}^{4}\right]^{+} ; 490\left[\mathrm{MnL}^{4}\left(\mathrm{C}(\mathrm{CN})_{2}\right)\right]^{+}$. IR (potassium bromide, $\left.\mathrm{cm}^{-1}\right): v_{\text {asym }}(\mathrm{C} \equiv \mathrm{N}) 2260$ $(\mathrm{m}), v_{\mathrm{sym}}(\mathrm{C} \equiv \mathrm{N}) 2147(\mathrm{vs}), v(\mathrm{C}-\mathrm{O}) 1252(\mathrm{~s}), v(\mathrm{C}=\mathrm{N}) 1624(\mathrm{vs}), v(\mathrm{O}-\mathrm{H}) 3420(\mathrm{~m}) . \mu=5.0 \mathrm{BM} .{ }^{1} \mathrm{H}$ NMR (dimethylsulfoxide- $\left.\mathrm{d}_{6}, \mathrm{ppm}\right): \delta-24.55(\mathrm{H} 4),-15.81(\mathrm{H} 5) . \mathrm{E}_{\mathrm{ox}}=-0.116 \mathrm{~V} ; \mathrm{E}_{\mathrm{red}}=-0.256 \mathrm{v} ; \mathrm{E}_{1 / 2}=$ -0.186 V. $\Lambda_{\mathrm{M}}=74 \mu \mathrm{S}$.

$\mathrm{MnL}^{4}\left(\mathrm{H}_{2} \mathrm{O}\right)_{2}\left(\mathrm{ClO}_{4}\right)(6)$ was obtained by the same procedure as 3, using $0.6 \mathrm{~g}(1.62 \mathrm{mmol})$ of $\mathrm{H}_{2} \mathrm{~L}^{4}$, $0.59 \mathrm{~g}(1.62 \mathrm{mmol})$ of $\mathrm{Mn}\left(\mathrm{ClO}_{4}\right)_{2} \cdot 6 \mathrm{H}_{2} \mathrm{O}$ and $0.13 \mathrm{~g}(3.24 \mathrm{mmol})$ of $\mathrm{NaOH}$. Experimental details are available in the Supplementary Materials section. Yield: $0.71 \mathrm{~g} \mathrm{(82 \% ).} \mathrm{Calculated} \mathrm{Elemental} \mathrm{Analysis}$ for $\mathrm{C}_{21} \mathrm{H}_{28} \mathrm{ClMnN}_{2} \mathrm{O}_{10}$ (558.8): $\mathrm{C}, 45.1 ; \mathrm{H}, 5.0 ; \mathrm{N}$, 5.0. Found: $\mathrm{C}, 45.4 ; \mathrm{H}, 4.8 ; \mathrm{N}, 5.1 \%$. MS ES $(\mathrm{m} / \mathrm{z})$ : $423\left[\mathrm{MnL}^{4}\right]^{+}$. IR (potassium bromide, $\left.\mathrm{cm}^{-1}\right): v_{3}\left(\mathrm{ClO}_{4}^{-}\right) 1122(\mathrm{vs}), v(\mathrm{C}-\mathrm{O}) 1307(\mathrm{~s}), v(\mathrm{C}=\mathrm{N}) 1612(\mathrm{vs})$, $v(\mathrm{O}-\mathrm{H}) 3420(\mathrm{~m}) . \mu=5.0 \mathrm{BM} .{ }^{1} \mathrm{H}$ NMR (dimethyl sulfoxide-d $\mathrm{d}_{6}, \mathrm{ppm}$ ): $\delta-20.96$ (H4), -16.27 (H5). $\Lambda_{\mathrm{M}}=81 \mu \mathrm{S}$.

\subsection{Peroxidase Probes}

Oxidation of the reactant ABTS (2,2'-azinobis-(3-ethylbenzothiazoline)-6-sulfonic acid) with hydrogen peroxide in buffered solutions at $\mathrm{pH} 6.8$ in the presence of the complexes 1-7 was tested according to the literature procedure $[17,27]$. To prevent undesired photochemical processes [28], illumination at wavelengths shorter than $455 \mathrm{~nm}$ should be avoided, so the radical absorbance at $650 \mathrm{~nm}$ was selected to follow the peroxidase activity [28]. The intensity of the ultraviolet (UV) absorption bands of the radical species started to increase immediately after addition of the oxidant. Spectra were recorded every $30 \mathrm{~s}$, and the data is taken from the spectra recorded $10 \mathrm{~min}$ after mixing. 


\subsection{Electrochemical Oxidations of Veratryl Alcohol (VA)}

Oxidations of VA to VAH were performed using an Iso-tech laboratory DC power supply model IPS 303DD. The experiments were carried out in a beaker $(100 \mathrm{~mL})$ fitted with a rubber bung, through which the electrochemical leads from the DC power supply entered the cell. Platinum wires were used as electrochemical leads. The electrochemical cell was placed in a thermostatted water bath at temperature of $23^{\circ} \mathrm{C}, 40^{\circ} \mathrm{C}$ or $50{ }^{\circ} \mathrm{C}$. In a typical experiment, the $75 \mathrm{~mL}$ buffered solutions ( $\mathrm{pH}$ 8.25) containing the complexes 1-7 $\left(1.35 \times 10^{-6}\right.$ mol for $1 \%$, but the amount of complex catalyst was evaluated in the range from 0 to $3 \%)$ and sodium chloride $(2.1 \mathrm{~g})$ as a supporting electrolyte were thermostatted at $40^{\circ} \mathrm{C}$. Then VA $(19 \mu \mathrm{L})$ was added, and the preset current was applied using the DC power supply at a fixed potential for $2 \mathrm{~h}$.

During the experiment, hydrogen gas evolved at the cathode. The solution was connected to a UV spectrophotometer through a peristaltic pump and a flow cell. Using this setup we were able to continuous record the electronic spectra of the solution and measure the rate of a VAH production. After electrochemical reaction, catalyst was removed by filtrating the solution through a short silica gel plug. The filtered solution was then separated in dichloromethane in the presence of saturated aqueous sodium chloride solution. The organic fraction was dried over magnesium sulphate and evaporated under reduced pressure. The residue was purified by column chromatography using a 1:1 mixture of ethyl acetate/hexane as eluent, and the ${ }^{1} \mathrm{H}$ NMR spectrum was recorded.

Table 1 summarizes some of the experimental conditions for the electrochemical oxidations of VA to $\mathrm{VAH}$.

Table 1. Experimental conditions for the electrochemical conversion of VA to VAH ( $\left.\mathrm{pH} 8.25 ; 40{ }^{\circ} \mathrm{C} ; 4 \mathrm{~V}\right)$.

\begin{tabular}{ccccc}
\hline Compound & TON $^{\mathbf{a}}$ & $\mathbf{m m o l}$ VA Converted to VAH & Amount $(\mathbf{m g})$ of VA Oxidized & Ef $^{\mathbf{b}} / \mathbf{m o l ~ F}^{\mathbf{1}}$ \\
\hline 1 & 84 & $5.70 \times 10^{-2}$ & 9.580 & 0.31 \\
2 & 84 & $5.64 \times 10^{-2}$ & 9.485 & 0.30 \\
3 & 68 & $4.57 \times 10^{-2}$ & 7.686 & 0.25 \\
4 & 80 & $5.39 \times 10^{-2}$ & 9.065 & 0.29 \\
5 & 40 & $2.73 \times 10^{-2}$ & 4.592 & 0.15 \\
6 & 40 & $2.73 \times 10^{-2}$ & 4.591 & 0.15 \\
7 & 40 & $2.67 \times 10^{-2}$ & 4.491 & 0.14 \\
\hline
\end{tabular}

${ }^{a}$ Turnover number; ${ }^{b}$ Electrochemical efficiency of the cell, defined as the amount of VA converted to VAH per Faraday of charge.2.4. Crystallographic Studies.

Single crystals of 1 suitable for X-ray diffraction (XRD) studies were obtained by slow evaporation of methanolic solutions at room temperature.

Table 2 summarizes the detailed crystallographic data and refinement parameters for 1 . Measurements were made on a Bruker X8 APEXII CCD diffractometer employing graphitemonochromated $\mathrm{Mo}-\mathrm{K} \alpha$ radiation at cryogenic temperature $(100 \mathrm{~K})$. The structures were solved by direct methods [29] and finally refined by full-matrix least- squares base on $\mathrm{F}^{2}$. An empirical absorption correction was applied using the program for empirical absorption correction of area detector data SADABS [30]. All non-hydrogen atoms were included in the model at geometrically calculated positions.

Refinement of $\mathrm{F}^{2}$ against all reflections. The weighted $\mathrm{R}$-factor $\mathrm{wR}$ is based on $\mathrm{F}^{2}$, conventional $R$-factors $R$ are based on $F$, with $F$ set to zero for negative $F^{2}$. The threshold expression of $F^{2}>2 \sigma\left(F^{2}\right)$ is used only for calculating R-factors(gt) etc. and is not relevant to the choice of reflections for refinement. $\mathrm{R}$-factors based on $\mathrm{F}^{2}$ are statistically about twice as large as those based on F, and R-factors based on ALL data will be even larger. Molecular graphics were done with ORTEP (Oak Ridge Thermal Ellipsoid Plot program) [31] and Mercury [32]. 
Table 2. Crystal data and structure refinement for $\mathbf{1}$.

\begin{tabular}{|c|c|}
\hline Empirical formula & $\mathrm{C}_{22} \mathrm{H}_{24} \mathrm{Mn} \mathrm{N}_{5} \mathrm{O}^{5}$ \\
\hline Formula weight & 493.40 \\
\hline Temperature $[\mathrm{K}]$ & $100(2)$ \\
\hline Wavelength $[\AA]$ & 0.71069 \\
\hline Crystal system & Monoclinic \\
\hline Space group & $\mathrm{P} 21 / \mathrm{c}$ \\
\hline a $[\AA ̊]$ & $13.0012(3)$ \\
\hline $\mathrm{b}[\AA]$ & $13.1768(4)$ \\
\hline$c[\AA]$ & $13.7748(4)$ \\
\hline$\alpha\left[^{\circ}\right]$ & 90 \\
\hline$\beta\left[^{\circ}\right]$ & $110.325(2)$ \\
\hline$\gamma\left[{ }^{\circ}\right]$ & 90 \\
\hline Volume [̊̊3] & $2212.89(11)$ \\
\hline $\mathrm{Z}^{\mathrm{L}}$ & 4 \\
\hline Density (calculated) $\left[\mathrm{g} \mathrm{cm}^{-3}\right]$ & 1.481 \\
\hline Absorption coefficient $\left[\mathrm{mm}^{-1}\right]$ & 0.641 \\
\hline $\mathrm{F}(000)$ & 1024 \\
\hline Theta range for data collection $\left[{ }^{\circ}\right]$ & 1.67 to 27.87 \\
\hline Reflections collected & 34,661 \\
\hline Independent reflections & 5273 \\
\hline Final $\mathrm{R}$ indices $[\mathrm{I}>2 \operatorname{sigma}(\mathrm{I})]$ & $\mathrm{R} 1=0.0299 ; \mathrm{wR} 2=0.0689$ \\
\hline $\mathrm{R}$ indices (all data) & $\mathrm{R} 1=0.0410 ; \mathrm{wR} 2=0.0722$ \\
\hline
\end{tabular}

\section{Results}

\subsection{Synthesis and Characterization of the Complexes}

Manganese(III)-Schiff base complexes 1-7 were obtained in high yield as outlined in the experimental section. Characterization of complexes 2 [26], 4 [17] and 7 [27] has been already reported, so results and discussion of this section will be focused on compounds 1, 3, 5 and 6 .

Elemental analysis establish a formula $\mathrm{Mn}_{2} \mathrm{~L}_{2}{ }_{2}\left(\mathrm{H}_{2} \mathrm{O}\right)_{2}\left(\mathrm{~N}(\mathrm{CN})_{2}\right)_{2}$ for $\mathbf{1}, \mathrm{MnL}^{3}\left(\mathrm{H}_{2} \mathrm{O}\right)_{2}\left(\mathrm{ClO}_{4}\right)$ for 3, $\mathrm{Mn}_{2} \mathrm{~L}_{2}^{4}\left(\mathrm{H}_{2} \mathrm{O}\right)_{2}\left(\mathrm{~N}(\mathrm{CN})_{2}\right)_{2}$ for 5 , and $\mathrm{MnL}^{4}\left(\mathrm{H}_{2} \mathrm{O}\right)_{2}\left(\mathrm{ClO}_{4}\right)$ for 6; other analytical and spectroscopic techniques support these formulations and give further insight into the structure of the complexes. Thus, the conductivity measurements in millimolar dimethylformamide solutions are in agreement with non-electrolyte behaviors of the $\mathrm{Mn}$ (III) complexes [33], and the magnetic moment values measured at room temperature are very close to the spin-value of 4.9 B.M., as expected for a high-spin magnetically diluted $\mathrm{d}^{4}$ manganese(III) ions.

IR spectra for all the complexes exhibit a strong band between $1612-1624 \mathrm{~cm}^{-1}$ characteristic of the $v(\mathrm{C}=\mathrm{N})$ stretching mode of the Schiff base. This band in the Mn(III) coordinated complexes is shifted $5-14 \mathrm{~cm}^{-1}$ lower with respect to the free Schiff base ligands, indicating the coordination to the manganese through nitrogen atoms of the imine group. The band attributed to the $v(C-O)$ mode is shifted to higher frequencies with respect to the free ligands. Two new bands, at 2152-2147 and $2268-2260 \mathrm{~cm}^{-1}$ in $\mathbf{1}$ and $\mathbf{5}$, were observed and assigned to the symmetric and asymmetric dicyanamide modes, respectively [34]. The broad unsplit band at about $1120 \mathrm{~cm}^{-1}$ in 3 and 6 is indicative of the presence of the uncoordinated perchlorate anion [35], its characteristic $v_{4}$ stretching mode at ca. $630 \mathrm{~cm}^{-1}$ can also easily be identified.

Paramagnetic ${ }^{1} \mathrm{H}$ NMR spectra of 1-7 were registered using dimethylsulfoxide- $\mathrm{d}_{6}$ as solvent. When applied to solutions of paramagnetic metal compounds, a significant line broadening and large paramagnetic chemical shifts are often observed in the NMR spectra providing evidence of paramagnetic metal-ligand coordination [36]. Our NMR spectra (Figure 1) show both paramagnetic signatures: the significant line broadening and the chemical shift range. For 1-7, the spectra contain two upfield proton resonances (see Figure 1) from the protons in the aromatic phenoxy rings. The signals 
appear outside the diamagnetic region $(\delta=0-14 \mathrm{ppm})$, due to the hyperfine couplings of the Schiff base ligand protons to high-spin $\mathrm{d}^{4}$ manganese(III).

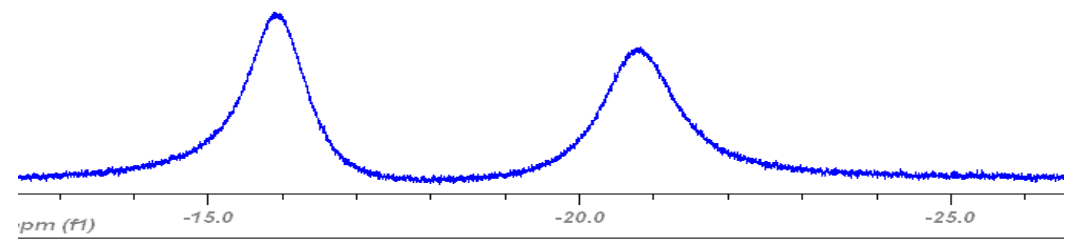

Figure 1. Example of paramagnetic ${ }^{1} \mathrm{H}$ nuclear magnetic resonance (NMR) spectrum, in this case corresponding to 6 .

Parallel-mode electron paramagnetic resonance (EPR) spectroscopy (microwave field $B_{1}$ is parallel to the static field $B_{0}$ ) enables the detection of EPR transitions in non-Kramer spin systems (with integer electron spins), often unobservable using conventional perpendicular-mode EPR $\left(B_{1} \perp B_{0}\right)$ [37]. $\mathrm{Mn}^{3+}$ has an integer electron spin, $S=2$, and has been shown in frozen solutions to develop a characteristic six-line pattern in parallel-mode EPR [38]. Figure 2 collects the parallel-mode EPR spectra measured for four complexes studied in the present work. For complexes $\mathbf{1}$ and $\mathbf{3}$, the six-line EPR pattern is centered at $g_{\text {eff }}=8.08$ and split by a hyperfine coupling $A_{\|}=42-43 \mathrm{G}$ due to a ${ }^{55} \mathrm{Mn}$ nuclear spin $(I=5 / 2)$. For compounds 5 and $\mathbf{6}$, the EPR spectra are distinctly different, with the six-line pattern centered at $g_{\text {eff }}=8.16$ and split by $A_{\|}=49 \mathrm{G}$. The larger $g_{\text {eff }}$ in 5 and $\mathbf{6}$ indicates a stronger ZFS rhombicity (a larger orthorhombic distortion in the ligand field symmetry) in these complexes [39]. The larger $A_{\|}$may be attributed to a decreased covalency of the chelating $\mathrm{N}_{2} \mathrm{O}_{2}$ atoms because of a wider bite-angle (longer Mn-O and Mn-N distances) in 5 and $\mathbf{6}$ as compared to 1 and 3 [39].

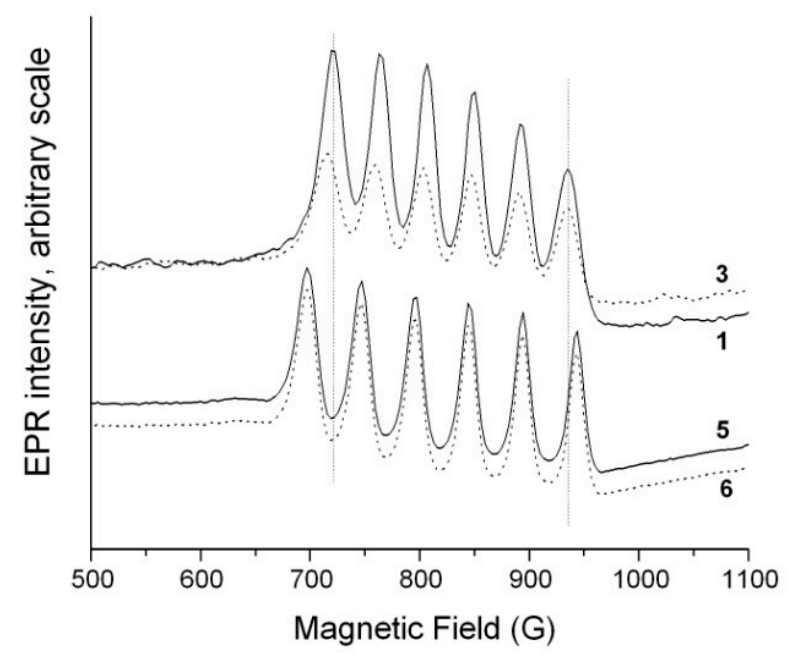

Figure 2. Parallel-mode electron paramagnetic resonance (EPR) spectra of 1, 3, 5 and $\mathbf{6}$ in frozen Toluene: dimethylformamide: $\mathrm{EtOH}$ (2:1:drop) solutions. EPR conditions: microwave frequency, $9.37 \mathrm{GHz}$; temperature, $6 \mathrm{~K}$; microwave power, $2 \mathrm{~mW}$.

Cyclic voltammetry indicates that the electrochemical behavior of the complexes, with both reduction and oxidation waves, can be defined as quasi-reversible. The low $\mathrm{E}_{1 / 2}$ values in the range -54 to $-196 \mathrm{mV}$ are in accordance with the electron-donor character for the selected substituents (methoxy or ethoxy) on the phenolato rings. The redox waves, corresponding to the $\mathrm{Mn}{ }^{\mathrm{III}} / \mathrm{Mn}^{\mathrm{II}}$ redox couple of the complexes, exhibit peak to peak separation in the range 80 to $140 \mathrm{mV}$, which varies with the scan rate, showing a more reversible character at slower scan rates. Table 3 collects the $\mathrm{E}_{\mathrm{ox}}\left(\mathrm{Mn}^{\mathrm{II}} \rightarrow \mathrm{Mn}^{\mathrm{III}}\right)$ and $\mathrm{E}_{\text {red }}\left(\mathrm{Mn}^{\mathrm{III}} \rightarrow \mathrm{Mn}^{\mathrm{II}}\right)$ potentials for the complexes. The cyclic voltammogram for 3 is illustrated in Figure 3. 
Table 3. VA to VAH conversion, peroxidase activity, $\mathrm{Mn}-\mathrm{O}_{\text {axial }}$ distances, EPR hyperfine coupling and redox potentials for the complexes.

\begin{tabular}{ccccccc}
\hline Compound & VA to VAH $^{\mathbf{a}}$ & Peroxidase Activity $^{\mathbf{b}}$ & $\mathbf{M n}-\mathbf{O}_{\text {axial }} \mathbf{c}^{\mathbf{c}}$ & $\boldsymbol{A}_{\|} \mathbf{d}$ & $\mathbf{E}_{\mathbf{o x}}(\mathbf{V})$ & $\mathbf{E}_{\text {red }}(\mathbf{V})$ \\
\hline 1 & $42.2 \pm 4$ & $65 \pm 5$ & $2.2495(11)$ & 43 & -0.085 & -0.165 \\
2 & $41.8 \pm 3$ & $35 \pm 1$ & $2.257(2)$ & 42 & -0.010 & -0.098 \\
3 & $38.5 \pm 5$ & $54 \pm 5$ & un. & 43 & -0.034 & -0.114 \\
4 & $39.9 \pm 6$ & $50 \pm 3$ & $2.270(6)$ & 42 & -0.154 & -0.237 \\
5 & $20.2 \pm 3$ & $2.2 \pm 0.4$ & un. & 49 & -0.116 & -0.256 \\
6 & $20.1 \pm 2$ & $2.4 \pm 0.3$ & un. & 49 & un. & un. \\
7 & $19.8 \pm 3$ & $1.9 \pm 0.4$ & un. & un. & -0.034 & -0.144 \\
\hline
\end{tabular}

${ }^{\text {a }}$ Conversion rates of VA to VAH at $40{ }^{\circ} \mathrm{C}$ with $0.5 \%$ of catalyst at $\mathrm{pH} 8.25$; $^{\mathrm{b}}$ Peroxidase activity expressed as percentage of conversion of ABTS (2,2'-azinobis-(3-ethylbenzothiazoline)-6-sulfonic acid) to ABTS measured $10 \mathrm{~min}$ after mixing the solutions; ${ }^{\mathrm{c}}$ in angstroms; ${ }^{\mathrm{d} 55} \mathrm{Mn}$ Hyperfine coupling in EPR measurements.

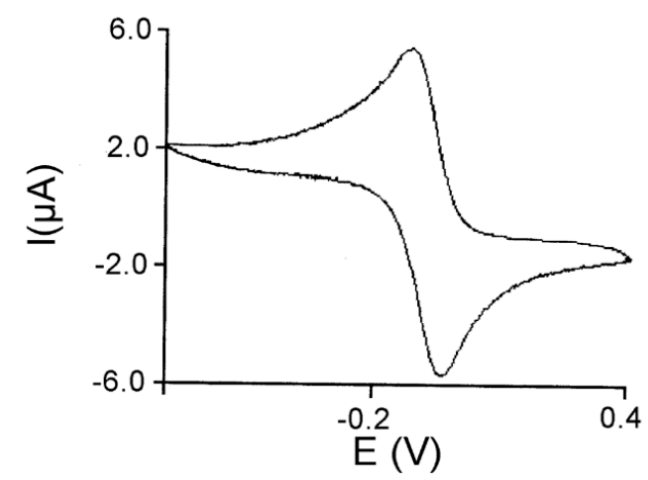

Figure 3. Cyclic voltammogram for 3 at scan rate of $0.02 \mathrm{~V} \mathrm{~s}^{-1}$.

\subsection{Crystal Structure of 1}

Single crystals of complex 1 , suitable for X-ray diffraction studies, were obtained as described in the 2.6 section of crystallographic studies. The crystal structure of the monomeric unit is shown in Figure $4 a$, while Figure $4 \mathrm{~b}$ shows the $\mu$-aquo dimers resulting from the non-covalent interactions between the monomers. Table 4 collects main bond distances, and Table 5 summarizes main angles for 1 .

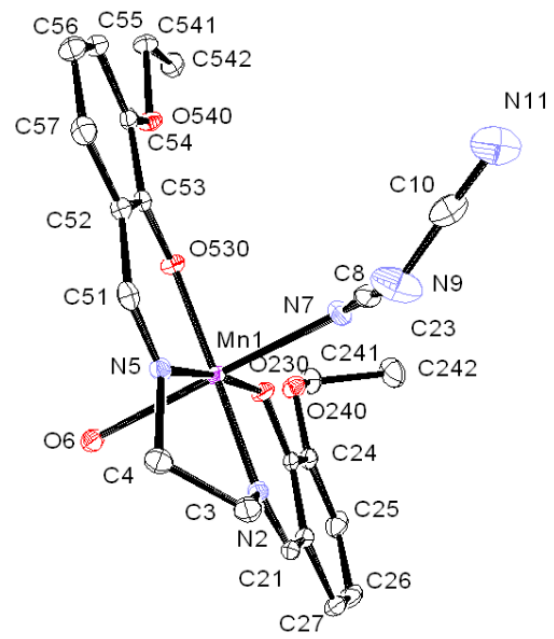

(a)

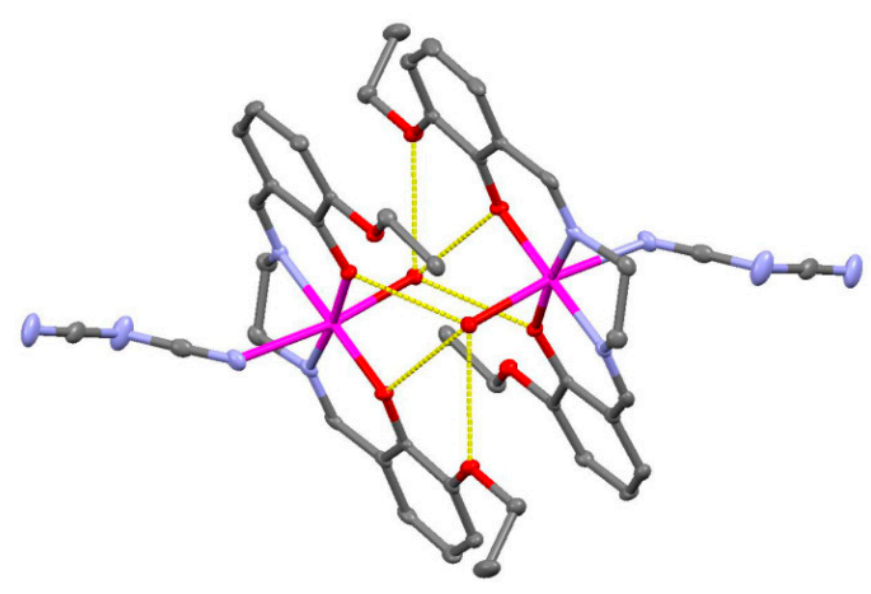

(b)

Figure 4. (a) ORTEP view of the monomeric unit for 1 with numbering scheme; (b) crystal structure of the dimeric entity for $\mathbf{1}$ (manganese ion in magenta, nitrogen in blue, oxygen in red and carbon in grey). 
Table 4. Selected bond lengths $(\AA)$ and angles $\left(^{\circ}\right)$ for $\mathbf{1}$.

\begin{tabular}{cccc}
\hline Mn1-O230 & $1.8837(10)$ & Mn1-O530 & $1.8895(10)$ \\
Mn1-N2 & $1.9834(12)$ & Mn1-N5 & $1.9828(13)$ \\
Mn1-O6 & $2.2495(11)$ & Mn1-N7 & $2.3037(13)$ \\
C4-N5 & $1.473(19)$ & N2-C3 & $1.474(19)$ \\
N5-C51 & $1.290(19)$ & N2-C21 & $1.287(2)$ \\
N7-C8 & $1.162(2)$ & C8-N9 & $1.301(2)$ \\
N9-C10 & $1.305(2)$ & C10-N11 & $1.154(2)$ \\
O230-Mn1-O530 & $94.19(4)$ & N2-Mn1-N5 & $82.26(5)$ \\
O230-Mn1-O6 & $93.45(5)$ & N5-Mn1-N7 & $85.62(5)$ \\
O230-Mn1-N2 & $92.11(5)$ & N7-Mn1-O6 & $168.90(5)$ \\
O230-Mn1-N5 & $173.87(5)$ & Mn1-N2-C3 & $113.35(9)$ \\
O230-Mn1-N7 & $96.56(5)$ & Mn1-N2-C21 & $125.68(11)$ \\
O530-Mn1-O6 & $92.79(5)$ & Mn1-N5-C4 & $113.15(9)$ \\
O530-Mn1-N5 & $91.48(5)$ & Mn1-N5-C51 & $126.00(10)$ \\
O530-Mn1-N7 & $91.25(5)$ & N2-Mn1-N7 & $87.15(5)$ \\
O530-Mn1-N2 & $173.64(5)$ & N2-Mn1-N5 & $82.26(5)$ \\
N2-Mn1-O6 & $87.70(5)$ & C21-N2-C3 & $120.97(13)$ \\
N5-Mn1-O6 & $83.95(5)$ & C51-N5-C4 & $120.84(13)$ \\
O230-Mn1-O530 & $94.19(4)$ & & \\
\hline
\end{tabular}

Table 5. Hydrogen bond scheme (distances and angles) for $\mathbf{1 .}$

\begin{tabular}{ccccc}
\hline D-H . . A & $\mathrm{d}(\mathbf{D}-\mathbf{H})$ & $\mathrm{d}(\mathbf{H} \ldots \mathbf{A})$ & $\mathrm{d}(\mathbf{D} \ldots$ A) & $<$ (DHA) \\
\hline O6-H6A..O530 [a] & $0.79(4)$ & $2.18(3)$ & $2.8509(17)$ & $143(2)$ \\
O6-H6A..O540 [a] & $0.79(4)$ & $2.37(2)$ & $3.0630(16)$ & $148(3)^{\prime}$ \\
O6-H6B..O230 [a] & $0.75(2)$ & $2.30(2)$ & $2.9300(16)$ & $142(2)$ \\
O6-H6B..O240 [a] & $0.75(2)$ & $2.35(2)$ & $3.0169(16)$ & $149(2)^{\prime}$ \\
C4-H4A..N11 [b] & 0.97 & 2.58 & $3.247(2)$ & 126 \\
C51-H51..N11 [c] & $0.934(19)$ & $2.337(19)$ & $3.229(2)$ & $159,5(15)$ \\
\hline
\end{tabular}

[a] $1-x, 1-y,-z .[b] 1 / 2-x, 1 / 2+y, z .[c] 2-x, 1 / 2+y, 1 / 2-z$.

The monomer is composed by an approximately octahedral $\left[\mathrm{MnL}^{1}\left(\mathrm{H}_{2} \mathrm{O}\right)\left(\mathrm{N}(\mathrm{CN})_{2}\right)\right]$ unit, with the Schiff base tetracoordinated to the metal ion through its oxygen-nitrogen-nitrogen-oxygen (ONNO) donor atoms. This coordination of the Schiff base in the equatorial plane forms three chelate rings with the metal ion (two six-membered and one five-membered), thus providing high stability to the $[\mathrm{MnL}]^{+}$ units. The bis-deprotonated Schiff base ligand is tightly bound to the manganese ion by the nitrogen iminic and oxygen phenolic atoms (Mn- $\mathrm{N}_{\text {imine }}$ bond lengths of 1.9828-1.9834 $\AA$ and $\mathrm{Mn}-\mathrm{O}_{\text {phenol }}$ of 1.8837-1.8895 ^ which are typical of such complexes [14-16]).

The distortion of the octahedron is derived from the considerably longer axial distances with respect to the equatorial ones. The axial positions are occupied by a capping water molecule (Mn-O6 with a bond distance of 2.2495(11) $\AA$ ) and a dicyanamide molecule (Mn-N7 with a bond distance of 2.3037(13) $\AA$ ). The ratio between the Mn-O axial and Mn-O equatorial distances in the crystal structure is 1.194, which is a way to express the tetragonal distortion factor for the octahedron around the manganese ion. This effect has been previously studied by us for this type of complex [17,27], and a correlation between the tetragonal distortion and the catalytic performance in different redox processes has been established $[17,27]$. This can be explained because the tetragonal elongation enhances the lability of an axial position where the substrate molecule can be subsequently accommodated in this site, following an inner-sphere electron-transfer mechanism.

A rich network of non-covalent interactions stabilizes dimeric entities by the extension of the monomeric units. The octahedral entities are linked in pairs by $\mu$-aquo bridges between the hydrogen atoms of the axial water molecules and the phenoxy and ethoxy oxygen atoms from the neighboring Schiff base ligands. $\pi-\pi$ stacking interactions between parallel aromatic rings from neighboring ligands are also enriching the final supramolecular structure. 


\subsection{Peroxidase and Electrolytical Studies}

Several water-soluble traps for radical species can be used for peroxidase assays [40]. In the present work we employed the diammonium salt of ABTS, which is commonly used with both natural peroxidases [41] and enzyme mimetics [42]. However, we recently found that photochemical processes, especially ${ }^{\bullet} \mathrm{OH}$ radical generation from $\mathrm{H}_{2} \mathrm{O}_{2}$, can lead to erroneous results in this test [28]. The level of $\mathrm{ABTS}^{\bullet+}$ can be grossly overestimated being affected by the illumination conditions and also the time at which absorbance readings are taken; many of these undesired effects can be avoided using illumination at wavelengths longer than $455 \mathrm{~nm}$. Conveniently, ABTS ${ }^{\bullet+}$ has several additional absorption bands at longer wavelengths including 650, 735 and $815 \mathrm{~nm}$. The extent of the reaction, avoiding photochemical interferences, can be measured quantitatively at $\lambda=650 \mathrm{~nm}$ since $\varepsilon=12,000 \mathrm{M}^{-1} \mathrm{~cm}^{-1}$ has been determined.

When using 1-4, the observed rates of formation of $\mathrm{ABTS}^{\bullet+}$ were about $35-65 \%$ indicating a high peroxidase activity (see Table 3). On the other hand, complexes 5-7 did not show any measurable peroxidase-like activity with the $\mathrm{UV}$ absorbances from the $\mathrm{ABTS}^{\bullet+}$ radical cation being negligible even after 60 min of illumination.

VA is commonly used as a lignin model compound $[43,44]$. This substrate was ideal for our experiments as complexes 1-7 do not absorb at $310 \mathrm{~nm}$ where the oxidised product VAH absorbs strongly $\left(\varepsilon=9300 \mathrm{M}^{-1} \mathrm{~cm}^{-1}\right.$; Figure S2) [45]. Experiments of electrochemical oxidation of VA to VAH were carried out using $\mathrm{NaCl}$ as electrolyte in order to increase the conductivity of water and to reduce the power dissipation. Other than improving on ionic conductivity, it was found that chloride ions could significantly reduce the adverse effect of other anions such as carbonate or sulphate. The concentration of the electrolyte has a marked influence on the cell efficiency. The addition of increasing amounts of $\mathrm{NaCl}$ led to higher conversion ratios of VA into VAH (Figure S3).

The formation of VAH was confirmed after its isolation and characterisation by ${ }^{1} \mathrm{H}$ NMR. The ${ }^{1} \mathrm{H}$ NMR spectrum of the VAH fraction confirmed the disappearance of the $\mathrm{CH}_{2}$ proton signal at $4.61 \mathrm{ppm}$ from the VA precursor as well as the appearance of a new peak at $9.62 \mathrm{ppm}$ from the aldehyde product (VAH, Figure S4).

Temperature is another factor that leads to an increase in the conversion ratio. It was found that a significant improvement could be achieved when the experiments were carried out at $40{ }^{\circ} \mathrm{C}$ rather than room temperature (thermostatted $23^{\circ} \mathrm{C}$ ), although a further increase in temperature to $50{ }^{\circ} \mathrm{C}$ did not show any significant increase in the conversion ratio (Figure S5). The electrocatalytic studies at different $\mathrm{pH}$ values were mainly carried out at $40^{\circ} \mathrm{C}$ and an $\mathrm{NaCl}$ concentration close to that of sea water, the most important source of water on earth and also accessible for the pulp industry.

We also examined the effect of catalyst concentration on the VA conversion rate by varying a molar concentration of the catalyst against the VA concentration in the range from $0.25 \%$ to $3 \%$. The highest conversion rates (Figure S6) were achieved when using $0.5 \%$ of the catalyst complex. The highest turnover numbers (TON), above 100 per $\mathrm{Mn}(\mathrm{III})$, were achieved using $0.25 \%$ of catalyst complex (Table 1). The use of complexes 1-7 as electrocatalysts enhanced the conversion rates for the VA oxidation to VAH at all tested driving potentials (Figure S7). The results obtained at driving potential $4 \mathrm{~V}$ in the presence/absence of catalysts after $2 \mathrm{~h}$ are represented in Figure 5 and selected data are shown in Tables 4 and 5 . The catalysts seem to be stable for longer periods, in fact highest VA to VAH conversion rates can be gradually achieved for times up to $8 \mathrm{~h}$ although this causes a considerably loss of the electrochemical efficiency. 


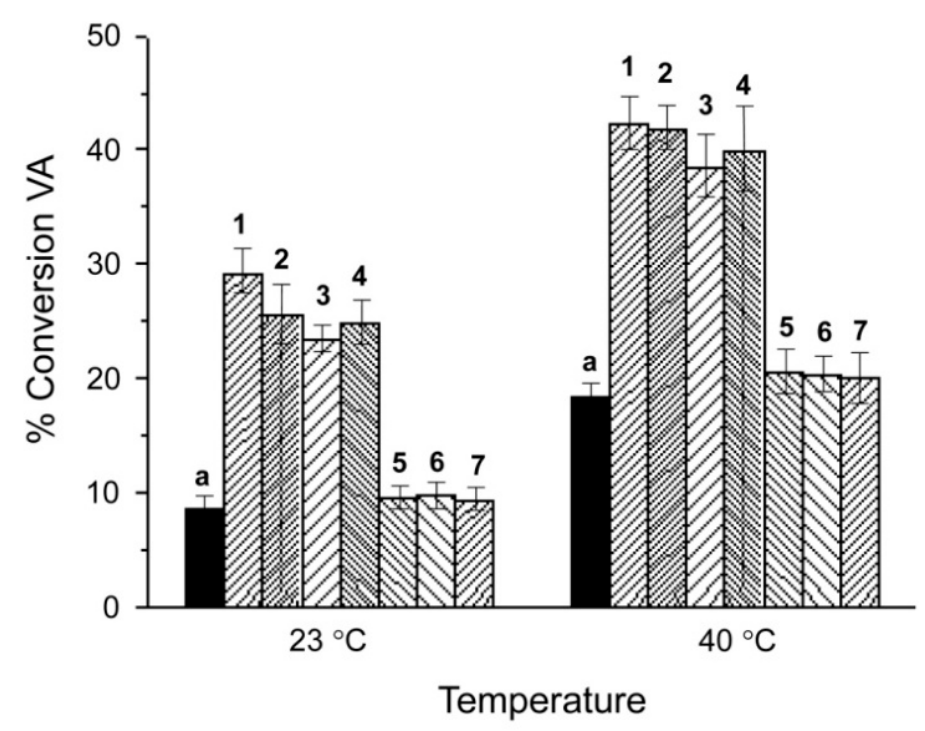

Figure 5. Conversion rates of veratrylalcohol (VA) to veratrylaldehyde (VAH) at 23 and $40{ }^{\circ} \mathrm{C}$ after $2 \mathrm{~h}$ without catalyst (a) and with catalysts (1-7); $\mathrm{pH}=8.25$.

Complex 1, which produces the highest conversion rates, led to an increase in the formation of veratryl aldehyde at $23{ }^{\circ} \mathrm{C}$ from 8.6 (without catalyst) to $29.2 \%$. At $40{ }^{\circ} \mathrm{C}$ the conversion without catalyst was $18.4 \%$ and increased markedly to $42.2 \%$ when using complex $\mathbf{1}(0.5 \%)$ as an electrocatalyst.

$\mathrm{pH}$ dependence of the conversion rates was examined in the $\mathrm{pH}$ range from 5 to 8.5. The yield results for complex $\mathbf{1}$ are compared to that without any catalyst in Figure 6. The conversion rates obtained using the catalyst are lower at acidic-neutral $\mathrm{pH}$, but these rates improve from $\mathrm{pH} 7.5$ to $\mathrm{pH}$ 8.25. The maximum conversion was achieved at $\mathrm{pH} 8.25$.

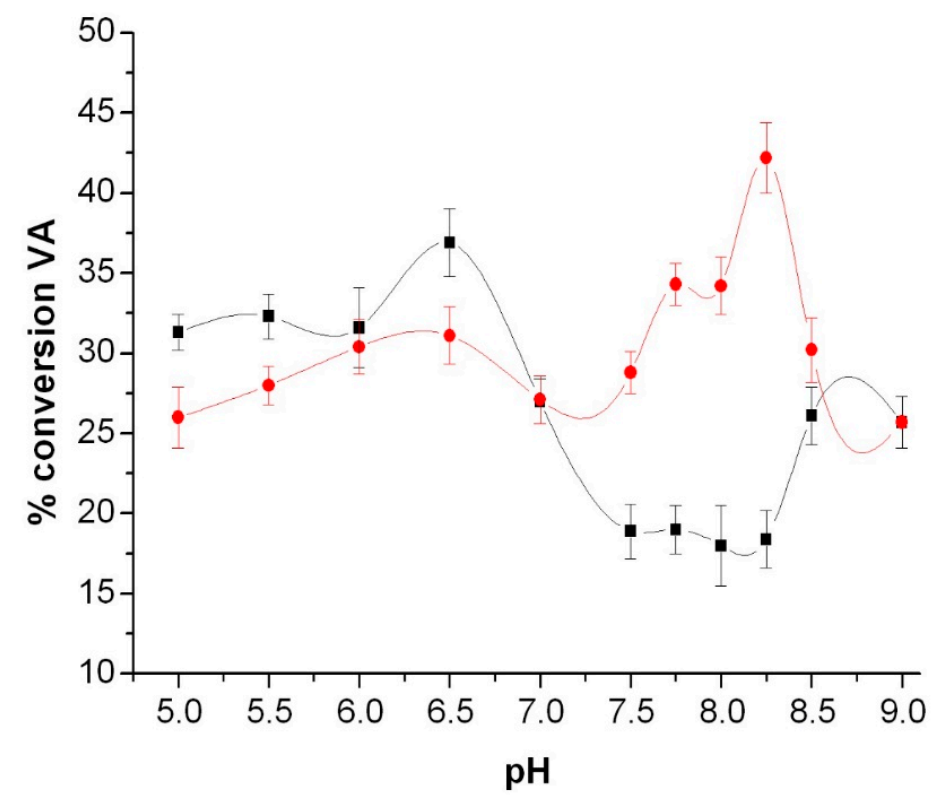

Figure 6. pH-dependence of conversion ratio of VA to VAH catalysed by $\mathbf{1}(\mathbf{\bullet})$, and without catalyst $(\boldsymbol{\omega})$ (at $40{ }^{\circ} \mathrm{C}$ ).

\section{Discussion}

The conversion rates obtained for electrochemical oxidation of VA to VAH are particularly high considering the mild conditions used in our experiments as compared to the experimental setups reported by other authors, where high temperatures and pressures were required to achieve 
similar yields with different catalysts $[46,47]$. Moreover, most of the oxygen-activating homogeneous transition-metal catalysts were investigated in organic solvents and only a few are known to be active in water [48].

A better electrocatalytic performance displayed by 1-4 in comparison to 5-7 may be explained by the difference in their Schiff base ligand structures. We have already proposed that improved catalytic performance, for different processes (peroxidase, catalase activities), may be associated with the ability of substrate (VA) molecules to coordinate directly to manganese(III). The coordination is favored if the catalyst has either a vacancy in the coordination sphere or a labile ligand [17]. The short two-carbon link between imine groups in 1-4 results in tighter confinement of the nitrogen atoms coordinated to the metal and to stronger tetragonal elongation distortion to the octahedral geometry of the cluster. An axial water molecule in this class of distorted geometries is quite a labile ligand, the loss of which would generate a vacant position in the coordination sphere to accommodate the substrate molecule. On the other hand, the flexible three-membered alkyl chain between the imine groups in the manganese compounds 5-7 favours more relaxed confinement and thus better stabilization of more symmetric octahedral geometry, which consequently makes the generation of an axial vacant site more difficult.

The structural difference between 1-4 and 5-7 is evident from our parallel-mode EPR data (Figure 2, Table 3). Complexes 1 and 3 demonstrate lower $g_{\text {eff }}=8.08$ (smaller orthorhombic distortion in the ligand field) and smaller $A_{\|}=42-43 \mathrm{G}$ (higher metal-ligand covalencies for the equatorially coordinated $\mathrm{N}_{2} \mathrm{O}_{2}$ atoms) as compared to the complexes 5 and 6 with $g_{\text {eff }}=8.16$ and $A_{\|}=49 \mathrm{G}$ [49]. The increased Mn-ligand covalency (a larger fraction of unpaired spin density being delocalized from the metal orbitals to the ligand orbitals [39]) indicates a smaller net positive charge on the center $\mathrm{Mn}$ (III) ion in case of complexes 1-4. This immediately results in a weaker binding of the axial ligands to $\mathrm{Mn}(\mathrm{III})$ which become more mobile and readily exchangeable for the VA substrate molecules. The higher covalency (smaller positive charge) also causes a shift in Mn(III) redox potentials in 1-4 to more negative which may further contribute to their improved overall performance as the catalyst. The catalytic performance of the complexes is definitely influenced by their redox potentials. Negative $E_{1 / 2}$ versus SCE and reversible electrochemical behaviors usually lead to better performances. Nevertheless, comparison between redox potentials (see Table 3) in 1-4 and 5-7 reveals that the redox potentials are not the determining factor in the obtained catalytic rates for this case. For instance, the active compound 4 shows the lowest $E_{1 / 2}$ value $(-196 \mathrm{mV})$, but the second lowest value $(-186 \mathrm{mV})$ corresponds to the inactive complex 5.

The clear correlation between the peroxidase activity and the conversion rates for the electrochemical oxidation of VA reinforces the idea that both processes can follow similar mechanisms. While binding of hydrogen peroxide to manganese ion is a key-step in the peroxidase activity (favored for 1-4 versus 5-7), binding of the sacrificial oxidant $\left(\mathrm{Cl}_{2} / \mathrm{HClO} / \mathrm{ClO}^{-}\right)$can become the determining step in the electrolytic experiments with VA.

Electrochemical studies at different $\mathrm{pH}$ provide additional insight into the equilibrium interplay between three oxidizing species, $\mathrm{Cl}_{2} / \mathrm{HClO} / \mathrm{ClO}^{-}$, potentially involved in the electrochemical reaction. A change in the concentration of $\mathrm{H}^{+}$or $\mathrm{OH}^{-}$shifts the equilibrium making one or another oxidising species to dominate in the media. Degradation of the lignin analogue in acidic media is mediated by the chorine formed in the anodic reaction. This process is responsible for the conversion rates at $\mathrm{pH}$ values below 7 in the presence or absence of complexes. The main reactions at the electrodes in acidic conditions are [50]:

$$
\begin{gathered}
\text { Anode: } 2 \mathrm{Cl}^{-} \rightarrow \mathrm{Cl}_{2}+2 \mathrm{e}^{-} \\
\text {Cathode: } 2 \mathrm{H}_{2} \mathrm{O}+2 \mathrm{e}^{-} \rightarrow \mathrm{H}_{2}+2 \mathrm{OH}^{-}
\end{gathered}
$$

In the aqueous acidic solution, hydrolysis of chlorine generates hypochlorous acid. The equilibrium constant for chlorine to hypochlorous acid is $4 \times 10^{-4}$ while that for hypochlorous acid to hypochlorite is $2.9 \times 10^{-8}$. This means that chlorine and hypochlorous acid are the most prevalent species at acidic 
$\mathrm{pH}[51,52]$. In the absence of an electrocatalyst, oxidation of veratryl alcohol tends to be greater at acidic $\mathrm{pH}$ than at alkaline $\mathrm{pH}$ due to the high oxidising activity of chlorine and hypochlorous acid.

At basic $\mathrm{pH}$ chlorine undergoes a disproportionation reaction to give chloride and hypochlorite:

$$
\mathrm{Cl}_{2}+2 \mathrm{OH}^{-} \rightarrow \mathrm{OCl}^{-}+\mathrm{Cl}^{-}+\mathrm{H}_{2} \mathrm{O}
$$

Consequently, hypochlorite is the prevalent oxidising agent under alkaline conditions [53]. A proportion of the useful hypochlorite ion is lost via the diffusion-controlled cathodic reduction to chloride and anodic oxidation to chlorate [50]:

$$
\mathrm{OCl}^{-}+\mathrm{H}_{2} \mathrm{O}+2 \mathrm{e}^{-} \rightarrow \mathrm{Cl}^{-}+2 \mathrm{OH}^{-}
$$

As a result of these processes, the conversion ratio of veratryl alcohol to veratryl aldehyde decreases at $\mathrm{pH} 7-8.25$ for the experiments carried out in the absence of a complex.

Interestingly, the electrocatalytic activity of complex 1 reaches a maximum at $\mathrm{pH} 8.25$, which means that reaction occurs in a chlorine-free medium with hypochlorite used as a sacrificial oxidant. The rate of degradation of the lignin model by electrochemical oxidation under these conditions is higher than in every $\mathrm{pH}$ media. The results obtained at $\mathrm{pH} 8.25$ clearly indicate that this oxidation is mediated by complex 1 , which acts as an efficient electrocatalyst.

The sum of reactions (1)-(4) represents the global process:

$$
2 \mathrm{H}_{2} \mathrm{O}+2 \mathrm{e}^{-} \rightarrow \mathrm{H}_{2}+2 \mathrm{OH}^{-}
$$

The novel approach outlined above avoids the use of chlorine by simply adjusting to an alkaline $\mathrm{pH}$. Ideally, photovoltaic electric current would be able to induce the oxidation of chloride into hypochlorite along with the formation of hydrogen. Any hydrogen released could be used in fuel cells to generate electricity, and this would reduce the energy consumption of the global process. The use of catalysts leads to a significant increase in the efficiency of the oxidation of the lignin model. The robustness of the catalysts makes them suitable for use in a wide range of conditions. Electrocatalytic generation of hydrogen from water is one of the potential applications of this type of complex and studies in this respect are underway.

We assessed whether the catalytic behavior of this type of complex is affected by variations in the skeleton of the organic Schiff base ligand. Experiments are also ongoing with the aim of enhancing this activity by tuning the steric and electronic effects around the manganese core. Our aim is to define the appropriate choice of bulky and/or electron-withdrawing or -donating substituents to be incorporated in the Schiff bases.

Supplementary Materials: The following are available online at http:/www.mdpi.com/2076-3417/9/16/3430/s1: Experimental details for materials and methods; Figure S1: Stick diagram for 1 showing the hydrogen bonding network; Table S1: Compound formula, structure of Schiff base ligand and reference; Figure S2: Evolution over time of the ultraviolet-visible (UV-Vis) spectra in the electrochemical cell using 1 as catalyst; Figure S3: Conversion of VA to VAH catalysed by 1 using different $\mathrm{NaCl}$ concentrations; Figure S4: ${ }^{1} \mathrm{H}$ NMR spectrum $\left(\mathrm{in}_{\mathrm{CDCl}}\right.$ ) of the VAH isolated product after electrocatalytic oxidation of VA; Figure S5: Conversion of VA to VAH at different temperature using catalysts 1 and 3; Figure S6: Conversion of VA to VAH using different concentrations of catalyst 1; Figure S7: Conversion of VA to VAH at different potentials.

Author Contributions: Conceptualization, M.M.; Data curation, L.R., G.G.-R., A.M.T.; Formal analysis, M.I.F.-G., A.M.G.-N.; Investigation, L.R., M.I.F.-G., G.G.-R., A.M.G.-N.; Supervision, M.M.; Writing-Original draft, L.R. and M.M.; Writing—Review and Editing, L.R., A.M.T., M.I.F.-G. and M.M.

Funding: This research was funded by Xunta de Galicia (GRC GI-1584-ED431C2018/13 Suprabioin Research Group, and MetalBIO Network ED431D 2017/01).

Conflicts of Interest: The authors declare no conflict of interest. 


\section{References}

1. Behling, R.; Valange, S.; Chatel, G. Heterogeneous catalytic oxidation for lignin valorization into valuable chemicals: What results? What limitations? What trends? Green Chem. 2016, 18, 1839-1854. [CrossRef]

2. Kärkäs, M.D.; Matsuura, B.S.; Monos, T.M.; Magallanes, G.; Stephenson, C.R. Transition-metal catalyzed valorization of lignin: The key to a sustainable carbon-neutral future. Org. Biomol. Chem. 2016, 14, 1853-1914. [CrossRef] [PubMed]

3. Haritash, A.K.; Kaushik, C.P. Biodegradation aspects of polycyclic aromatic hydrocarbons (PAHs): A review. J. Hazard. Mat. 2009, 169, 1-15. [CrossRef] [PubMed]

4. Isroi, I.; Millati, R.; Syamsiah, S.; Niklasson, C.; Cahyanto, M.N.; Ludquist, K.; Taherzadeh, M.J. Biological pretreatment of lignocelluloses with white-rot fungi and its applications: A review. BioResources 2011, 6, 5224-5259. [CrossRef]

5. Pokhrel, D.; Viraraghavan, T. Treatment of pulp and paper mill wastewater-A review. Sci. Total Environ. 2004, 333, 37-58. [CrossRef] [PubMed]

6. Muñoz, I.; Rieradevall, J.; Torrades, F.; Peral, J.; Domènech, X. Environmental assessment of different advanced oxidation processes applied to a bleaching Kraft mill effluent. Chemosphere 2006, 62, 9-16. [CrossRef] [PubMed]

7. Chen, C.L.; Capanema, E.A.; Gracz, H.S. Reaction mechanisms in delignification of pine Kraft-AQ pulp with hydrogen peroxide using Mn (IV)-Me4DTNE as catalyst. J. Agric. Food Chem. 2003, 51, 1932-1941. [CrossRef]

8. Rochefort, D.; Leech, D.; Bourbonnais, R. Electron transfer mediator systems for bleaching of paper pulp. Green Chem. 2004, 6, 14-24. [CrossRef]

9. Hage, R.; Lienke, A. Applications of transition-metal catalysts to textile and wood-pulp bleaching. Angezw. Chem. Int. Ed. 2006, 45, 206-222. [CrossRef]

10. Song, Q.; Wang, F.; Cai, J.; Wang, Y.; Zhang, J.; Yu, W.; Xu, J. Lignin depolymerization (LDP) in alcohol over nickel-based catalysts via a fragmentation-hydrogenolysis process. Energy Environ. Sci. 2013, 6, 994-1007. [CrossRef]

11. Hanson, S.K.; Baker, R.T. Knocking on wood: Base metal complexes as catalysts for selective oxidation of lignin models and extracts. Acc. Chem. Res. 2015, 48, 2037-2048. [CrossRef] [PubMed]

12. Wang, Y.; De, S.; Yan, N. Rational control of nano-scale metal-catalysts for biomass conversion. Chem. Commun. 2016, 52, 6210-6224. [CrossRef] [PubMed]

13. Yadav, M.; Bista, G.; Maharjan, R.; Poudyal, P.; Mainali, M.; Sreerama, L.; Joshi, J. Secretory laccase from Pestalotiopsis Species CDBT-F-G1 fungal strain isolated from high altitude: Optimization of its production and characterization. Appl. Sci. 2019, 9, 340. [CrossRef]

14. Eckard, A.D.; Muthukumarappan, K.; Gibbons, W. A review of the role of amphiphiles in biomass to ethanol conversion. Appl. Sci. 2013, 3, 396-419. [CrossRef]

15. Corma, A.; Iborra, S.; Velty, A. Chemical routes for the transformation of biomass into chemicals. Chem. Rev. 2007, 107, 2411-2502. [CrossRef] [PubMed]

16. Zakzeski, J.; Bruijnincx, P.C.; Jongerius, A.L.; Weckhuysen, B.M. The catalytic valorization of lignin for the production of renewable chemicals. Chem. Rev. 2010, 110, 3552-3599. [CrossRef] [PubMed]

17. Vázquez-Fernández, M.Á.; Bermejo, M.R.; Fernández-García, M.I.; González-Riopedre, G.; Rodríguez-Doutón, M.J.; Maneiro, M. Influence of the geometry around the manganese ion on the peroxidase and catalase activities of Mn (III)-Schiff base complexes. J. Inorg. Biochem. 2011, 105, 1538-1547. [CrossRef]

18. González-Riopedre, G.; Fernández-García, M.I.; Gómez-Fórneas, E.; Maneiro, M. Biomimetic catalysts for oxidation of veratryl alcohol, a lignin model compound. Catalysts 2013, 3, 232-246. [CrossRef]

19. González-Riopedre, G.; Bermejo, M.R.; Fernández-García, M.I.; González-Noya, A.M.; Pedrido, R.; Rodríguez-Doutón, M.J.; Maneiro, M. Alkali-metal-ion-directed self-assembly of redox-active manganese(III) supramolecular boxes. Inorg. Chem. 2015, 54, 2512-2521. [CrossRef]

20. Rouco, L.; Fernández-García, M.; Pedrido, R.; Botana, L.; Esteban-Gómez, D.; Platas-Iglesias, C.; Maneiro, M. Modeling the OEC with two new biomimetic models: Preparations, structural characterization, and water photolysis studies of a Ba-Mn box type complex and a $\mathrm{Mn}_{4} \mathrm{~N}_{6}$ planar-diamond cluster. Catalysts 2018, 8, 382. [CrossRef]

21. Liu, W.; Groves, J.T. Manganese porphyrins catalyze selective C- H bond halogenations. J. Am. Chem. Soc. 2010, 132, 12847-12849. [CrossRef] [PubMed] 
22. Palopoli, C.; Duhayon, C.; Tuchagues, J.P.; Signorella, S. Synthesis, characterization, and reactivity studies of a water-soluble bis (alkoxo)(carboxylato)-bridged diMn III complex modeling the active site in catalase. Dalton Trans. 2014, 43, 17145-17155. [CrossRef] [PubMed]

23. Cozzi, P.G. Metal-Salen Schiff base complexes in catalysis: Practical aspects. Chem. Soc. Rev. 2014, 33, 410-421. [CrossRef] [PubMed]

24. Clarke, R.M.; Storr, T. The chemistry and applications of multimetallic salen complexes. Dalton Trans. 2014, 43, 9380-9391. [CrossRef]

25. Collinson, S.R.; Thielemans, W. The catalytic oxidation of biomass to new materials focusing on starch, cellulose and lignin. Coord. Chem. Rev. 2010, 254, 1854-1870. [CrossRef]

26. Vázquez-Fernández, M.Á.; Fernández-García, M.I.; González-Noya, A.M.; Maneiro, M.; Bermejo, M.R.; Rodríguez-Doutón, M.J. Supramolecular networks of Mn (III)-Schiff base complexes assembled by nitrate counterions: X-ray crystal structures of 1D chains and 2D networks. Polyhedron 2012, 31, 379-385. [CrossRef]

27. Bermejo, M.R.; Carballido, R.; Fernández-García, M.I.; González-Noya, A.M.; González-Riopedre, G.; Maneiro, M.; Rodríguez-Silva, L. Synthesis, Characterization, and Catalytic Studies of Mn (III)-Schiff Base-Dicyanamide Complexes: Checking the Rhombicity Effect in Peroxidase Studies. J. Chem. 2017. [CrossRef]

28. Liberato, A.; Fernández-Trujillo, M.J.; Máñez, A.; Maneiro, M.; Rodríguez-Silva, L.; Basallote, M.G. Pitfalls in the ABTS Peroxidase Activity Test: Interference of Photochemical. Proc. Inorg. Chem. 2018, 57, 14471-14475. [CrossRef]

29. Sheldrick, G.M. SHELX-97 (Shelxs 97 and Shelxl 97), Programs for Crystal Structure Analyses; University of Göttingen: Göttingen, Germany, 1998.

30. Sheldrick, G.M. SADABS, Program for Scaling and Correction of Area Detector Data; University of Göttingen: Göttingen, Germany, 1996.

31. Farrugia, L.J. ORTEP-3 for Windows-A version of ORTEP-III with a Graphical User Interface (GUI). J. Appl. Cryst. 1997, 30, 565. [CrossRef]

32. Macrae, C.F.; Bruno, I.J.; Chisholm, J.A.; Edgington, P.R.; McCabe, P.; Pidcock, E.; Rodriguez-Monge, L.; Taylor, R.; van de Streek, J.; Wood, P.A. MERCURY CSD 2.0-New features for the visualization and investigation of crystal structures. J. Appl. Crystallogr. 2008, 41, 466-470. [CrossRef]

33. Geary, W.J. The use of conductivity measurements in organic solvents for the characterisation of coordination compounds. Coord. Chem. Rev. 1971, 7, 81-122. [CrossRef]

34. Majumder, A.; Pilet, G.; Garlan, M.T.; Mitra, S. Synthesis and structural characterisation of three dicyanamide complexes with Mn (II), Zn (II) and Cd (II): Supramolecular architectures stabilised by hydrogen bonding. Polyhedron 2006, 25, 2550-2558. [CrossRef]

35. González-Riopedre, G.; Fernández-García, M.I.; González-Noya, A.M.; Vázquez-Fernández, M.A.; Bermejo, M.R.; Maneiro, M. Manganese-Schiff base complexes as catalysts for water photolysis. Phys. Chem. Chem. Phys. 2011, 13, 18069-18077. [CrossRef] [PubMed]

36. Bonadies, J.A.; Maroney, M.L.; Pecoraro, V.L. Structurally diverse manganese (III) Schiff base complexes: Solution speciation via paramagnetic ${ }^{1} \mathrm{H}$ NMR spectroscopy and electrochemistry. Inorg. Chem. 1989, 28 , 2044-2051. [CrossRef]

37. Hendrich, M.P.; Debrunner, P.G. Integer-spin electron-paramagnetic resonance of iron proteins. Biophys. J. 1989, 56, 489-506. [CrossRef]

38. Talsi, E.P.; Bryliakov, K.P. X-band perpendicular-mode EPR spectra of'EPR-silent'manganese (III) porphyrins. Mendel. Commun. 2004, 14, 111-112. [CrossRef]

39. Tyryshkin, A.M.; Watt, R.K.; Baranov, S.V.; Dasgupta, J.; Hendrich, M.P.; Dismukes, G.C. Spectroscopic evidence for $\mathrm{Ca}^{2+}$ involvement in the assembly of the $\mathrm{Mn}_{4} \mathrm{Ca}$ cluster in the photosynthetic water-oxidizing complex. Biochemistry 2006, 45, 12876-12889. [CrossRef]

40. Childs, R.E.; Bardsley, W.G. The steady-state kinetics of peroxidase with 2,2'-azino-di-(3-ethylbenzthiazoline-6-sulphonic acid) as chromogen. Biochem. J. 1975, 145, 93-103. [CrossRef]

41. Liu, S.W.; Xu, N.H.; Tan, C.Y.; Fang, W.; Tan, Y.; Jiang, Y.Y. A sensitive colorimetric aptasensor based on trivalent peroxidase-mimic DNAzyme and magnetic nanoparticles. Anal. Chim. Acta 2018, 1018, 86-93. [CrossRef] 
42. Díaz-Rubio, L.; Hernández-Martínez, R.; Estolano-Cobián, A.; Chávez-Velasco, D.; Salazar-Aranda, R.; Waksman de Torres, N.; Rivero, I.A.; García-González, V.; Ramos, M.A.; Córdova-Guerrero, I. Synthesis, biological evaluation and docking studies of chalcone and flavone analogs as antioxidants and acetylcholinesterase inhibitors. Appl. Sci. 2019, 9, 410. [CrossRef]

43. Rochefort, D.; Bourbonnais, R.; Leech, D.; Paice, M.G. Oxidation of lignin model compounds by organic and transition metal-based electron transfer mediators. Chem. Commun. 2002, 11, 1182-1183. [CrossRef]

44. Wu, X.; Guo, S.; Zhang, J. Selective oxidation of veratryl alcohol with composites of Au nanoparticles and graphene quantum dots as catalysts. Chem. Commun. 2015, 51, 6318-6321. [CrossRef] [PubMed]

45. Liu, A.; Huang, X.; Song, S.; Wang, D.; Xuemei, L.; Qu, Y.; Gao, P. Kinetics of the $\mathrm{H}_{2} \mathrm{O}_{2}$-dependent ligninase-catalyzed oxidation of veratryl alcohol in the presence of cationic surfactant studied by spectrophotometric technique. Spectrochim. Acta Part A 2003, 59, 2547-2551. [CrossRef]

46. Li, C.; Zhao, X.; Wang, A.; Huber, G.W.; Zhang, T. Catalytic transformation of lignin for the production of chemicals and fuels. Chem. Rev. 2015, 115, 11559-11624. [CrossRef] [PubMed]

47. Li, Z.; Garedew, M.; Lam, C.H.; Jackson, J.E.; Miller, D.J.; Saffron, C.M. Mild electrocatalytic hydrogenation and hydrodeoxygenation of bio-oil derived phenolic compounds using ruthenium supported on activated carbon cloth. Green Chem. 2012, 14, 2540-2549. [CrossRef]

48. Sippola, V.O.; Krause, A.O.I. Bis (o-phenanthroline) copper-catalysed oxidation of lignin model compounds for oxygen bleaching of pulp. Catal. Today 2005, 100, 237-242. [CrossRef]

49. Van Doorslaer, S.; Caretti, I.; Fallis, I.A.; Murphy, D.M. The power of electron paramagnetic resonance to study asymmetric homogeneous catalysts based on transition-metal complexes. Coord. Chem. Rev. 2009, 253, 2116-2130. [CrossRef]

50. Hine, F. Electrode Processes and Electrochemical Engineering; Plenum Press: New York, NY, USA, 1985.

51. Mukimin, A.; Wijaya, K.; Kuncaka, A. Oxidation of remazol brilliant blue r (RB. 19) with in situ electro-generated active chlorine using Ti/ $\mathrm{PbO}_{2}$ electrode. Sep. Purif. Technol. 2012, 95, 1-9. [CrossRef]

52. Chen, Z.; Concepcion, J.J.; Song, N.; Meyer, T.J. Chloride-assisted catalytic water oxidation. Chem. Commun. 2014, 50, 8053-8056. [CrossRef]

53. Szpyrkowicz, L.; Juzzolino, C.; Kaul, S.N.; Daniele, S.; de Faveri, M.D. Electrochemical oxidation of dyeing baths bearing disperse dyes. Indus. Eng. Chem. Res. 2000, 39, 3241-3248. [CrossRef]

(C) 2019 by the authors. Licensee MDPI, Basel, Switzerland. This article is an open access article distributed under the terms and conditions of the Creative Commons Attribution (CC BY) license (http://creativecommons.org/licenses/by/4.0/). 